
\title{
28 Research Suare \\ Debt Sustainability and Economic Growth: Evidence from Low Income Sub Saharan Africa Countries
}

Nitsuh Mengist Nega ( $\nabla$ nitsuhmengist@gmail.com )

Addis Ababa University

Research

Keywords: Sub-Saharan Africa, Panel data regression, Debt Sustainability, Hausman test.

Posted Date: May 5th, 2021

DOI: https://doi.org/10.21203/rs.3.rs-410424/v1

License: (c) (i) This work is licensed under a Creative Commons Attribution 4.0 International License.

Read Full License 


\title{
DEBT SUSTAINABILITY AND ECONOMIC GROWTH: EVIDENCE FROM LOW INCOME SUB SAHARAN AFRICA COUNTRIES
}

\author{
Author's Name: Nitsuh Mengist Nega ${ }^{1}$ \\ Institutional Address: Wolkite University, Ethiopia \\ Email Address: nitsuhmengist@gmail.com \\ THERE IS NO CORRESPONDING AUTHOR.
}

\footnotetext{
${ }^{1}$ The author completed both Bachelor of Degree (BA) in economics and Masters of Science (MSc.) in economic policy analysis from Addis Ababa University, Ethiopia. The author is now lecturer at Wolkite University, Ethiopia.
} 


\section{ABSTRACT}

The purpose of this study is to examine the effect of external public debt on economic growth and to assess the debt sustainability of twenty-four SSA countries over the period 2000-2017 using descriptive trend analysis and panel data analysis. The study found that external public debt has a negative and significant effect on the economic growth of low income SSA countries. The study also found that the external debt of low income SSA nations is unsustainable. In light of these findings, selected SSA countries should adopt a balance between external and domestic debt to ensure sustainable economic growth. They should also implement measures to promote export and expand domestic investment.

Keywords: Sub-Saharan Africa, Panel data regression, Debt Sustainability, Hausman test. 


\section{INTRODUCTION}

Many African countries have a problem to finance all of their development spending with the revenues they collect from domestic sources. As a result, they consider borrowing as a substantial source of financing to realize sustainable economic growth ${ }^{2}$. The countries borrow either from domestic or external sources or both. Domestic debt holds funds raised through financial assets and money borrowed from other locally-owned financial institutions. While, external debt generated from bilateral and multilateral sources. Governments' debt financing can help in this regard by channeling resources to projects where the rates of returns are at least sufficient to service the debt incurred.

Similarly, external debt classified as public and publicly guaranteed debt, private non-guaranteed debt, central bank deposits, and loans due to the IMF and WB (Greene and Khan, 1990). Public external debt refers to all foreign loans contracted between external creditors and the borrower country's Ministry of Finance, while publicly guaranteed external debt is contracted between credit suppliers and borrower countries public enterprises and guaranteed by the Ministry of Finance as well as the state-owned bank. Additionally, private non-guaranteed debt defined as loans contracted by public enterprises, mainly without government or government-owned bank guarantee (Irwin, 2015).

Debt has both negative and positive effects on economic growth. The first tenet of Keynesian economics agrees on the advantage of debt because, investments at all levels of government, corporation and individuals requires spending. Due to this, the government is forced to borrow money. Thus spending with debt stimulates the economy and desirable for future growth. On the contrary, the debt overhang hypothesis is the most commonly used argument to establish the adverse effect of external debt. The hypothesis states that when countries accumulate external debt, investors expect a higher future tax to service foreign debt. This reduces investment and, hence, adversely affects economic growth.

\footnotetext{
${ }^{2}$ Sustainable economic growth is economic development that attempts to satisfy the needs of humans but in a manner that sustains natural resources and the environment for future generations. Sustainable economic growth is a sole and most important factor to change the living standard of peoples (Buscemi and Alem, 2012).
} 
Beyond the adverse effect of debt, the countries borrowed a huge amount and not able to pay back. Thus in the 1980s, the world experienced a debt crisis in which, highly indebted Latin American and other developing regions were unable to repay their debt. The problem exploded in August 1982 as Mexico reported the failure to service its international debt, and a similar problem immediately expanded to the rest of the world (Harl 1990). Similarly, in the 1980s and 1990s, SSA countries debt burden increased to higher levels, and they become unable to pay back their debt (Kelbesa, 2014). Therefore, SSA countries' situations towards debt servicing and debt accumulation raise the issue of debt sustainability ${ }^{3}$.

A decade after the global financial crisis, global debt levels continue to reach new high record. The Institute of International Finance estimates that by the end of March 2018, global debt stocks had reached \$247.2 trillion, up from \$168 trillion at the onset of the financial crisis of 2007-2008 and by nearly $\$ 25$ trillion from a year earlier. UNCTAD estimates that the ratio of global debtto-world gross domestic product (GDP) is nearly one third higher than in 2008, with global debt stocks amounting to more than three times global GDP. The high dependence of a modest global recovery on debt reflects systemic fragilities in global growth dynamics that have persisted, despite the profound shock of the financial crisis (UNCTAD, 2018).

Several empirical studies identified the effect of external debt on growth and reached different conclusions. For instance, Greene (1989), Elbadawi et al. (1996), UNECA (1998), Iyoha (1999), and Mwaba (2001) conclude that accumulated external debt works against growth. On the other hand, a study by Tunde (2012), Matiti (2013), Zeaud (2014) and Njangang (2018) revealed that external debt helps a capital deficient nation to develop its productive activities and infrastructures. These dissimilarities of results suggest an ensuing controversy in the literature about the relationship between external debt and economic growth. Therefore, there is a need for further empirical investigation into the subject matter.

\footnotetext{
${ }^{3}$ Debt sustainability is the ability of a country to meet its debt obligations without requiring debt relief or accumulating arrears.
} 
This study contributes to the existing literature in the following ways. First, despite several studies on external debt, there has been little analysis in showing the effect of each type of external debt separately. In this study, an important distinction is made between public and private external debt hence the transmission channels are substantially different. This study gives an analysis of the impact of external public debt (public and publicly guaranteed) on the economic growth of selected SSA countries. Second, unlike previous studies, this study focuses on the debt crises of low-income ${ }^{4}$ SSA countries only that the concept of debt sustainability in low-income countries is different from that in middle-income countries. Third, the study incorporates the effect and sustainability level of external public debt of low-income SSA.

The purpose of this study is to investigating the effect of external public debt on the economic growth of low-income SSA countries; to analyze the trend of external public debt and economic growth and to examine the effects of other macroeconomic variables on economic growth.

\footnotetext{
${ }^{4}$ Low-income economies are defined as those with a GNI per capita, calculated using the World Bank Atlas method, of $\$ 995$ or less in 2017;
} 


\section{LITERATURE REVIEW}

Many researchers listed the types of actions to reduce debt accumulation; those are proposals to assist countries in meeting debt service obligations to multilateral organizations, measures for bilateral debt forgiveness, and more general debt forgiveness measures aimed at eliminating both bilateral and multilateral debt and providing all future assistance in the form of grants. Akcay et al. (2002) points to the necessity of a policy change towards fiscal austerity if insolvency is to be avoided in the medium to long term. Likewise Presbitero (2005) emphasizes debt relief initiatives should focus on creating fertile ground for macroeconomic stability.

Using different data and methodologies, various researchers have found negative external debteconomic growth nexus. Iyoha (1999) indicates that mounting external debt depresses investment through both a "disincentive" effect and a "crowding out" effect and debt stock reduction would have significantly increased investment and growth performance. Similarly, Presbitero (2005) underlines a large indebtedness leads to misallocation of capital and discourage long-term investment and structural reforms.

Even if a debt has an adverse effect on growth, the effect can be reduced or even reversed in the presence of sound macroeconomic policy. The policy measures include reducing the budget deficit, lowering inflation rate, and achieving trade openness. Presbitero (2005) emphasizes the critical role of economic policies and institutions with the necessity of focusing on LICs. As a result, debt relief initiatives should focus on creating fertile ground for macroeconomic stability. Moreover, Ramzan and Ahmad (2013) allowed external debt to interact with the macroeconomic policy index as an additional factor in the growth regression. They recommended policies that increase the inflow of Foreign Direct Investment are favorable.

On the contrary, other researchers (Matiti, 2013; Zeaud, 2014; Spilioti and Vamvoukas, 2014; and Cassimon et al., 2015) find that public debt positively affects economic growth in the steady 
area. For instance, Saifuddin (2016) indicates that public debt has made a significant contribution to economic growth not only directly but also indirectly via its effect on investment. The resources generated through public debt can basically used for productive investment in the countries. External debt helps a capital deficient nation to develop its productive activities and infrastructures. Government investments are financed by an additional resource from external debt and this contributes to economic growth.

Unlike the result of the above-listed studies, there are various researchers found a nonlinear relationship between public external debt and economic growth. Debt has a positive contribution to the economic growth of low-income countries, albeit up to a point, beyond the threshold it may start to drag economic growth. In this case, the government should finance its expenditure through other mechanisms than debt. Kelbesa (2014) found a bell-shaped relationship between economic growth and total public debt. Higher and lower debt values are associated with lower and higher growth rates, respectively. Similarly, Dogan and Bilgili (2014) describe the main growth variables such as investment and human capital have a positive impact on growth as expected; eventually, the conclusion reveals that the economic development and borrowing variables do not follow a linear path. Shahor (2018) suggested that at low levels of debt to GDP, an increase in debt can increase the long-run growth rate. But beyond a particular debt to GDP ratio, further improvements in the ratio will hurt growth. That means the regression curve has an inverted "U" shape. 


\section{METHODOLOGY}

The study used panel data for 24 SSA countries that are classified as low income based on a measure of national income per person, or GNI per capita. The data covers the period between 2000 and 2017 for all variables included in the study. This paper employed data from the World Bank's World Development Indicator (WDI) database, Global Development Finance database (World Bank), and supplemented with data from the World Economic Outlook database (IMF).

The study employed seven explanatory variables i.e., external public debt, external public debt service, investment, population, inflation, trade openness, and domestic debt. In this study, both descriptive statistics and econometric methods of data analysis are employed.

Econometric tests of debt sustainability consist of investigating whether export, import, and other debt sustainability indicators are co-integrated. The theoretical framework of this study is based on the Husted (1992) framework. Husted (1992) provides a simple small-economy framework in which a representative household is able to borrow and lend freely in international financial markets at a given world rate of interest. The representative agent's budget constraint derived as follows:

$\mathrm{Y}_{0}=\mathrm{C}_{0}+\mathrm{I}_{0}+\mathrm{NX}_{0} \quad$ where: $\mathrm{NX}_{0}=\mathrm{X}_{0}-\mathrm{M}_{0}$

Husted (1992) considers the above equation as a small open economy that produces and exports a single composite of good and has no government.

The agent is able to borrow and lend in international markets using one-period financial instruments, faces a given world rate of interest, and is assumed to maximize lifetime utility subject to budget constraints. The current period budget constraint of this agent is given in equation (2)

$\mathrm{C}_{0}=\mathrm{Y}_{0}+\mathrm{B}_{0}-\mathrm{I}_{0}-(1+1) \mathrm{B}_{-1} \quad$ where: $\mathrm{NX}_{0}=(1+\mathrm{r}) \mathrm{B}_{-1}-\mathrm{B}_{0}$

Where $\mathrm{Co}_{\mathrm{O}}$ is current consumption; $\mathrm{Y}_{\mathrm{O}}$ is output; $\mathrm{I}_{\mathrm{o}}$ is an investment; $\mathrm{r}_{\mathrm{o}}$ is the one-period world 
interest rate; $\mathrm{B}_{0}$ is international borrowing; and $\left(1+\mathrm{r}_{0}\right) \mathrm{B}_{-1}$ is the initial debt of the representative agents, corresponding to the country's external debt.

Husted (1992) suggested that equation (2) hold for every time period. Iterating equation (2) forward provides the economy's inter-temporal budget constraint.

$\mathrm{B}_{0}=\sum_{\mathrm{t}=1}^{\infty} \delta \mathrm{t} \mathrm{NX}+\lim _{\mathrm{n} \rightarrow \infty} \delta \mathrm{nBn}$

Where $N X t$ is the trade balance in period $\mathrm{t}$ which equals $\mathrm{NXt}=\mathrm{Xt}-\mathrm{Mt}=\mathrm{Yt}-\mathrm{Ct}-\mathrm{It}$, Xt equals export and Mtis import, and $\delta$ tis the discount factor or $\delta t=1 /(1+r) t$

A necessary and sufficient condition for external debt sustainability is that as $n \rightarrow \infty$, the discounted value of the external debt converges asymptotically to zero. This transversality condition can be expressed as:

$\operatorname{Lim}_{n \rightarrow \infty} \delta \mathrm{nBn}=0$

Equation (4) implies that a country cannot borrow (lend) indefinitely in global capital markets to finance its trade account deficit (surplus). If this transversality condition holds, then the amount of country borrows (lends) in international financial markets equals the present value of the future trade surplus (deficits). Thus, a test for the sustainability of the external debt can check for the co-integration of Mt and Xt. If they are I (1) this co-integration regression takes the following form:

$\mathrm{X}_{\mathrm{t}}=\mathrm{a}+\delta \mathrm{M}_{\mathrm{t}}+\mathrm{U}_{\mathrm{t}}$

Formally, if $\mathrm{M}_{\mathrm{t}}$ and $\mathrm{X}_{\mathrm{t}}$ are I (1), the null hypothesis is that $\mathrm{M}_{\mathrm{t}}$ and $\mathrm{X}_{\mathrm{t}}$ are co-integrated and $\delta=1$. If the null hypothesis is not rejected, then the external debt is said to be sustainable.

The theoretical foundation of this study is the augmented Solow model and endogenous growth model with a modification that extends the basic production function framework to permit human capital as an additional input into the production function following Romer (1996) and debt burden following Cunningham (1993). As implied by the Solow's formulation, economic growth is a function of capital accumulation, labor force, and exogenous technological progress 
which makes physical capital and labor more productive. According to the endogenous growth model, human capital influences economic growth as:

$\mathrm{Y}=\mathrm{f}(\mathrm{K}, \mathrm{HK}, \mathrm{LF}, \mathrm{A})$

Where $\mathrm{Y}$ is a proxy for economic growth; $\mathrm{K}$ is capital stock; HK represents Human capital; LF denotes labor force and $\mathrm{A}$ is technology. Although the endogenous growth model explains variables which affect economic growth, the model does not consider the impact of debt burden on economic growth. But Cunningham (1993) revealed debt burden is a vital determinant of economic growth especially, for those who are developing and highly indebted economies. Then after including debt burden as a new variable, the growth model can be expressed as:

$\mathrm{Y}=\mathrm{f}(\mathrm{K}, \mathrm{HK}, \mathrm{LF}, \mathrm{DB}, \mathrm{A})$

Where $\mathrm{Y}$ is a proxy for economic growth; $\mathrm{K}$ is capital stock; HK represents Human capital; LF denotes labor force; A is technology and DB is debt burden. To assess the impact of external debt on growth, in this study variables namely external public debt to GDP ratio and debt service to export ratio, are included in the standard growth model. In many of the studies, the ratio of the gross fixed domestic investment to GDP is employed as a proxy variable for capital stock. In this study, the researcher employs domestic investment including FDI as a proxy variable for K. In this study, I incorporate both human capital and labor force as labor and employs population growth as a proxy for rates of growth in labor as a factor input for the production process.

GDP is affected by other important variables, which must be included in the GDP equation in order to avoid specification bias in the debt-growth relationship. These control variables in this study include inflation rate, trade openness, and domestic debt. Openness measured by the total trade (sum of import and export of goods and services) as a ratio to GDP and reflects what extent an economic activity of a country is linked to the rest of the world.

Based on economic theories and using equation (7), this study modeled GDP growth as a function of external public debt (EPD), external public debt service (EPDS), investment (INV), population growth (POP), trade openness (TOP), Domestic debt(DOM), and inflation rate (INF). This relationship is expressed as: 


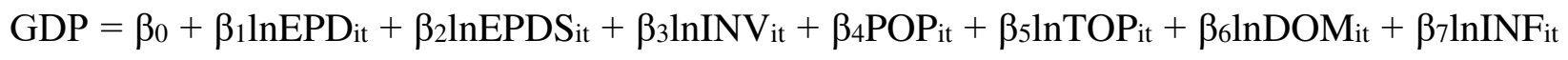

$+\mathrm{U}_{\text {it }}$

\section{EMPIRICAL RESULTS AND DISCUSSION}

\subsection{Trend Analysis of Variables}

The external public debt burden of low income SSA countries increased with a small amount in the early 2000s. While this burden decreased in 2005 mainly because of debt forgiveness under Multi-lateral Debt Relief Initiatives (MDRI). MDRI was approved on 2005 by Group of 8 major industrial countries proposed that the IMF, the World Bank, and the African development fund aimed to cancel 100 percent of their debt claims on countries that had reached, or would eventually reach, the "completion point" reached US\$ 100 billion for low income countries of SSA in 2017. Generally, external public debt is very high in lower-income SSA countries.

Figure 1 below demonstrates that the GDP rate for SSA associated with relatively less fluctuating rate of public external debt between 1970 and 2000. In the years between 2001 and 2010 low-income, SSA countries economic growth and rate of external public debt increased and decreased, respectively. The rate of external public debt shows improvement from the year 2013 to 2017. Bernardin et al. (2018) explained that even though many countries in the developing regions have managed to restore growth fortunes after the global economic distress of the 1980s, stagnation persisted in SSA into the first half of the 1990s due to the burden of external debt. The drastic decline in external debt rate starting from 2001 was on account of many SSA countries subscribing to debt relief under the highly indebted poor countries (HIPC) initiative. The improved growth performance witnessed following the declining debt burden could be indicating

\footnotetext{
${ }^{5}$ In order to receive full and irrevocable reduction in debt relief a country must met the following criteria's; first, establish a further track record of good performance under programs supported by loans from the IMF and the World Bank; second, Implement satisfactorily key reforms ; and third, Adopt and implement its Poverty Reduction Strategy Paper for at least one year. Once a country has met these criteria, it can reach its completion point (IMF factsheet, 2019).
} 
the increment of additional resources through reduced external debt service obligations to push growth.

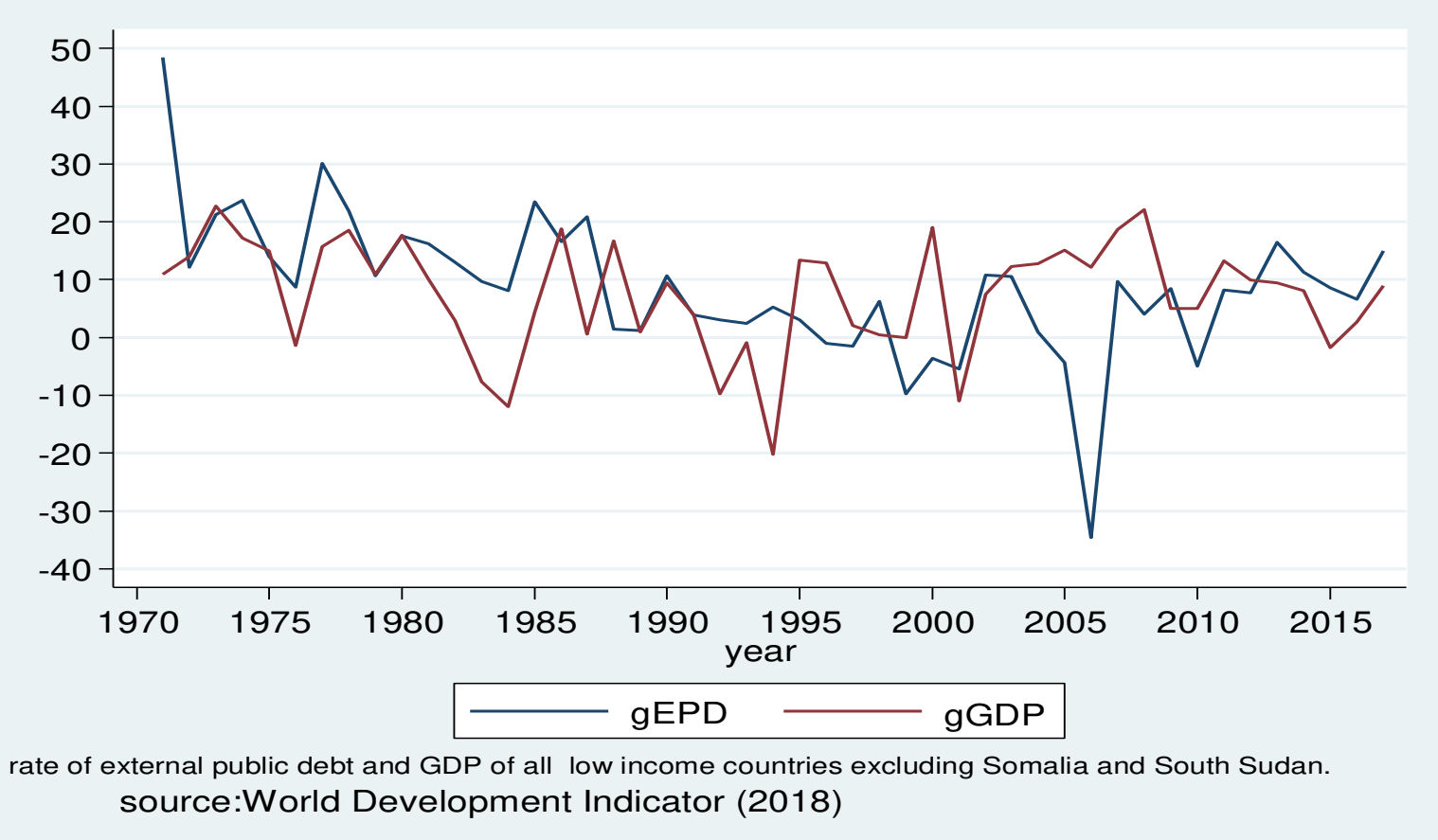

Figure 1: external public debt and economic growth of low-income SSA from 1970 to 2017.

The challenge facing SSA and the international community in the 1990s was how to service the external debt while resuming growth. Similarly, the balance between growth resumption and external debt service financing has become the most intractable problem facing low-income SSA nations. In figure 2 below the rate of external public debt service exceeds the growth of external public debt in the early 1970s. However, from the year 1980 to 1995, the rate of external public debt was higher than the rate of external public debt service. Low-income SSA countries external public debt service was US\$ 1.3 billion and external public debt was US\$ 17.6 billion in 1980. In the year 1995, external public debt service and external public debt were US\$ 2 and 64.6 billion, respectively. In recent years external public debt payment of low-income SSA countries shows small improvement due to the recorded improvement of economic growth. External public debt service was US\$ 3.5, 3, 3.7 and 4.1 billion in the years 2014 to 2017, respectively. 


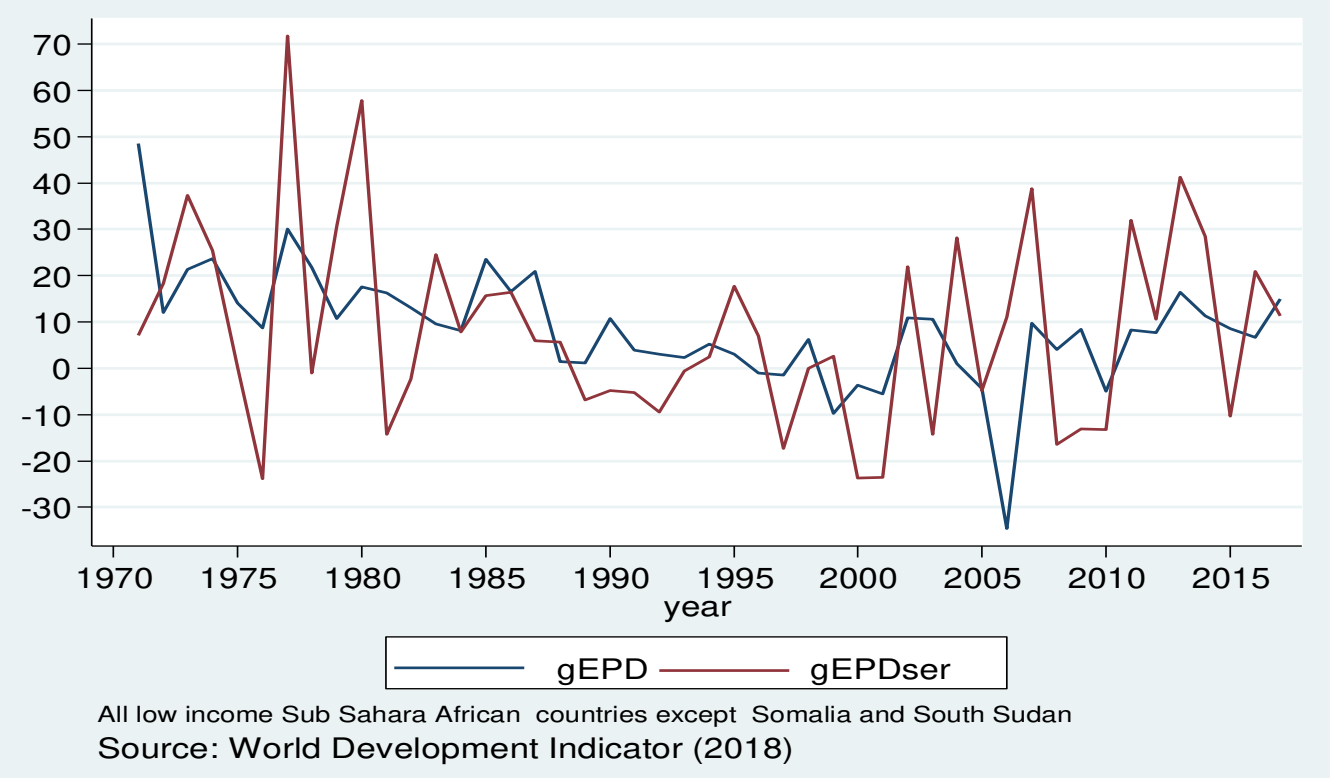

Figure 2: external public debt and external public debt service of low-income SSA from 1970 to 2017.

The composition of total external debt is an influential factor in debt analysis since it has a direct effect on the processes of debt repayment, rescheduling, and relief. External debt consists of three major divisions of debt; long term debt, short term debt, and IMF credit. Hence, long term debt consists of public and publicly guaranteed debt and private non-guaranteed debt. Due to the inconsistency of data for IMF credit, the researcher incorporates only long and short term debt in the chart below.

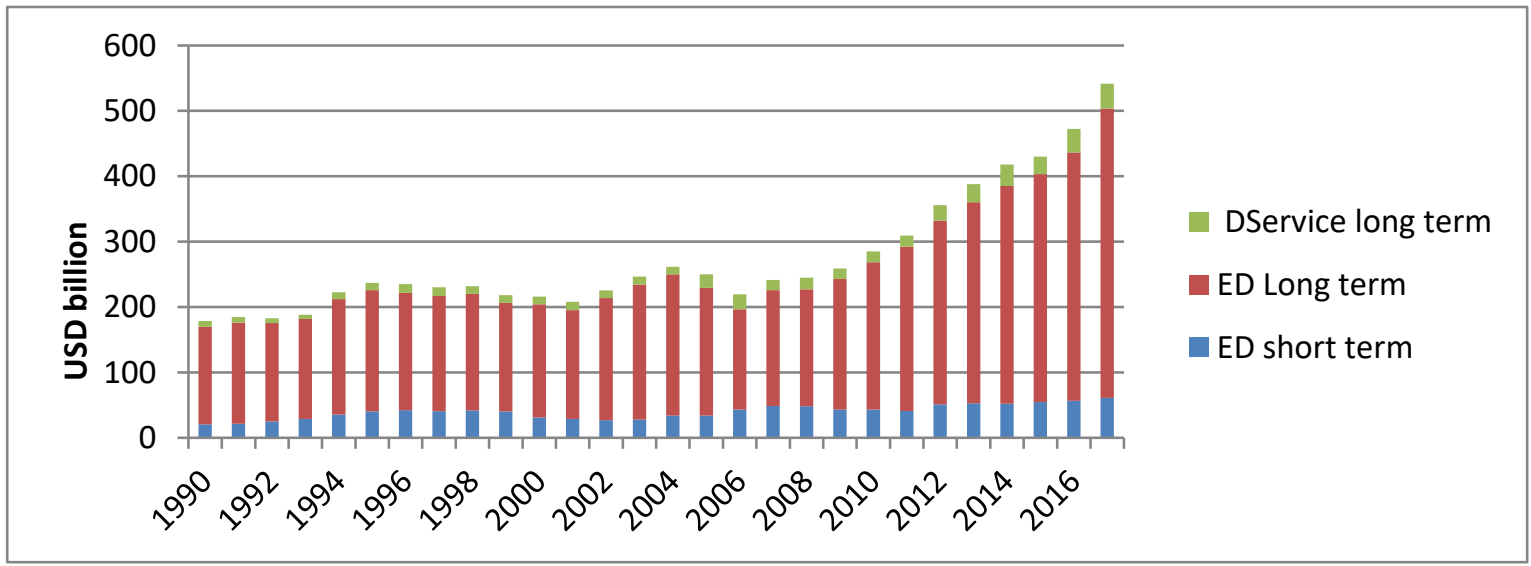

Figure 3: Composition of SSA total external debt and debt payment between years 1990 and 2017. Data for Seychelles, Somalia, and South Sudan not available 
The above figure explains that long term debt remained the largest component of external debt. In 1990 short term external debt, long term external debt, and long term debt service were US\$ 20.6 billion, US\$ 149 billion, and US\$ 9 billion, respectively. Starting from the year 2010 to 2017 a large increment in long term external debt was recorded. Short term external debt, the long term external debt, and long term debt service become US\$ 61 billion, US\$ 443 billion and US\$ 38 billion, respectively in 2017. From the graph above, it is concluded that short term and long term external debts had been increasing over time. But the growth rate of short term external debt was slow compared to long term external debt. The pattern of long term debt service indicates that SSA accumulated a substantial amount of arrears.

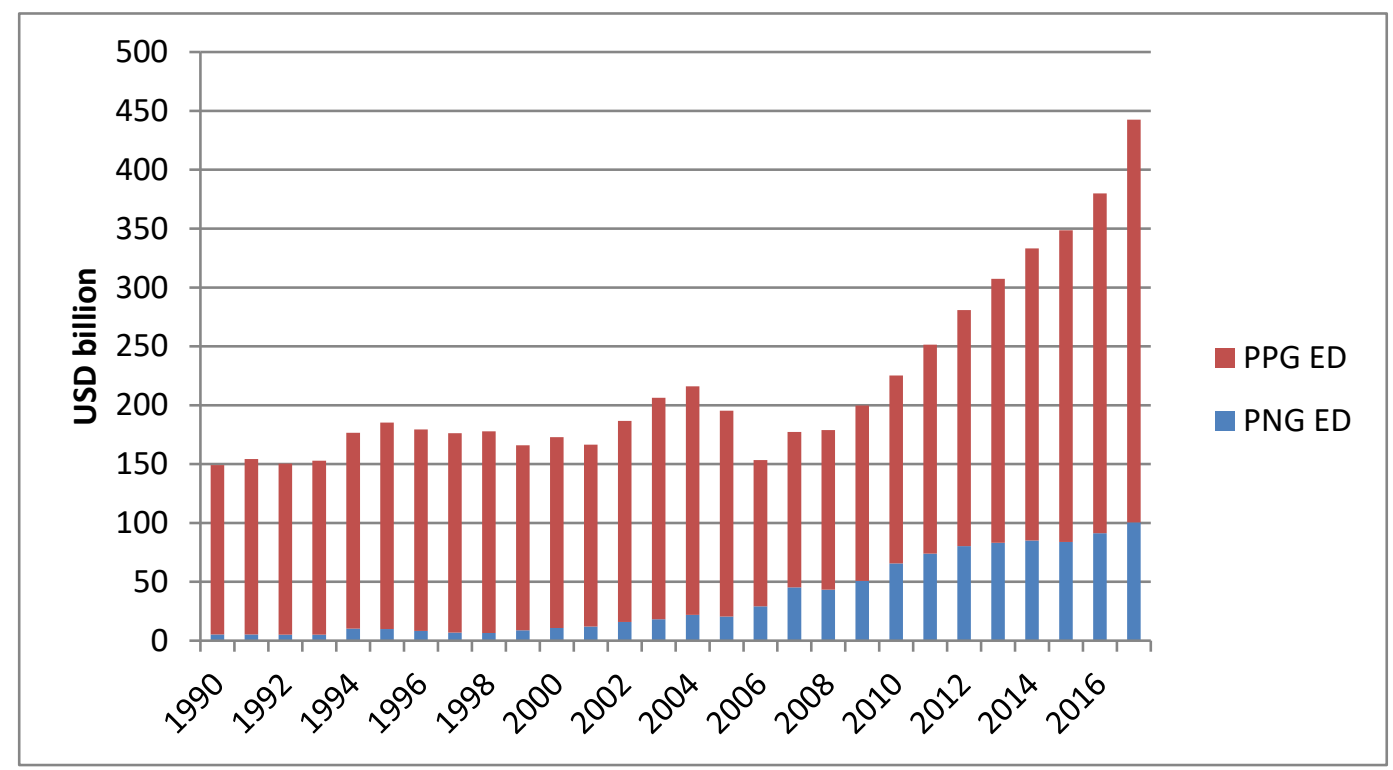

Figure 4: Composition of SSA long term external debt from 1990 to 2017. Data for Seychelles, Somalia, and South Sudan not available

The distribution of long term external debt into public and publicly guaranteed, and privately not guaranteed is necessary due to its bearing on the issues of financial access, debt repayment and relief (Fosu, 1996). It is clearly shown from figure 6 above that the largest share of external public debt is in the form of public and publicly guaranteed. In the year 1990 PPG and PNG were US\$ 144 billion and US\$ 5 billion, respectively. Debt forgiveness under the Highly Indebted Poor Countries Initiative (HIPC) in 1996 and debt forgiveness under Multi-lateral Debt Relief Initiatives (MDRI) in 2006 reduce the external debt burden. From the figure above, both PPG and PNG reach a higher point in 2017 and become US\$ 342 billion and US\$ 100 billion, 
respectively. The maximum and minimum value of PPG was recorded in Central Africa republic in 2008 and Comoros in 2015, respectively.

\subsection{Econometric Results}

The first step in the econometric analysis is to carry out a unit root test on the variables of interest. The test examines whether the variables are stationary or not. Non-stationary data has often been regarded as a problem in the empirical analysis. Working with non-stationary variables may lead to spurious regression results, from which further inference is meaningless. Panel unit root test is conducted based on Levin-Lin-Chu and ImPesaran-Shin test. The results from the tests are presented in table 1 below and all the variables except external public debt and external public debt services are stationary in level. External public debt and external public debt services are stationary at first difference. Hence, all the variables are integrated of order zero and one the basic conditions for the applications of other test are met and can move to the next step of the analysis.

Table 1: Unit Root test result

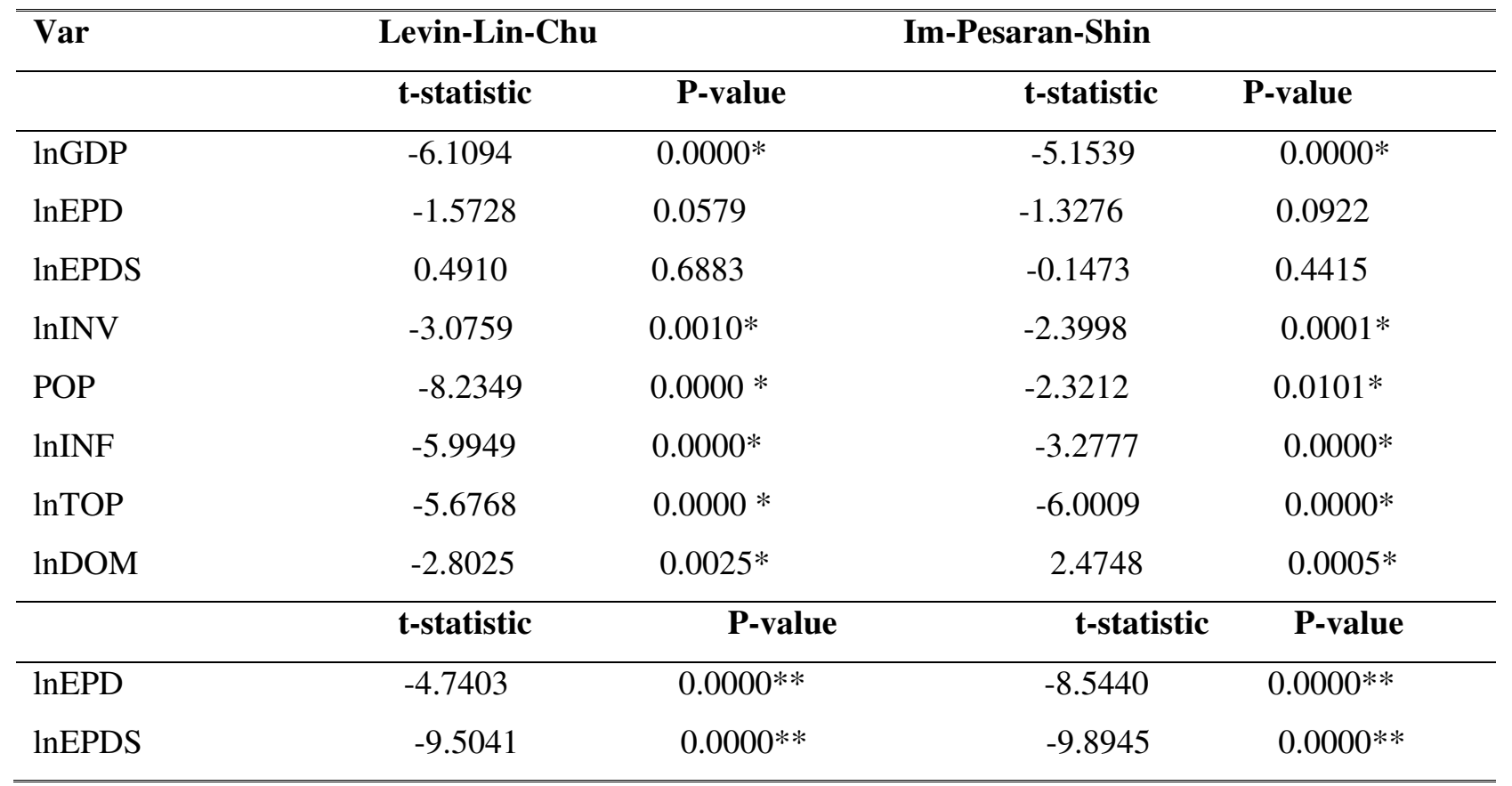

Source: Authors computation from the WDI (2018). The null hypothesis is non-stationarity and the alternative hypothesis is stationarity.* and ** indicates statistical significance at I (0) (level) and I (1) (first difference), respectively. 
There are three types of tests applied on debt sustainability indicators (external public debt to GDP ratio and external public debt service to export ratio), export and import to check the status of countries regarding their external debt sustainability. Those are univariate unit root tests, panel unit root tests, and panel co-integration tests.

Two univariate unit root tests are applied in this study to assess the external debt Sustainability of each low-income SSA countries. The test results of ADF and PP in level form have been generated and presented in the annex part. The univariate unit-root test statistics for all series fail to reject the unit-root null at the level at the 5\% significance level while; all series are stationary at first difference. As a result, the researcher turns to test panel unit root, and panel co-integration between the selected variables.

The study employed two panel unit root tests that are the Levin, Lin, and Chu, and the ImPesaran-Shin on the external debt sustainability indicators, export, and import. As it is shown in table 2 below all test statistics at first difference are found to reject the null hypothesis. Thus, the reported results confirmed that external debt is unsustainable and similar to the test result of the univariate unit root test; and leads to the third step of panel co-integration test.

Table 2: Panel Unit Root test result of debt sustainability indicators

\begin{tabular}{lccccc}
\hline & & \multicolumn{2}{c}{ Levin-Lin-Chu } & \multicolumn{2}{c}{ Im-Pesaran-Shin } \\
& Specification & t-statistic & P-value & t-statistic & P-value \\
\hline $\operatorname{lnEPD}$ & $1^{\text {st }}$ difference & -4.7403 & 0.0000 & -8.5440 & 0.0000 \\
$\operatorname{lnEPDS}$ & $1^{\text {st }}$ difference & -9.5041 & 0.0000 & -9.8945 & 0.0000 \\
$\operatorname{lnEXP}$ & $1^{\text {st }}$ difference & -5.6579 & 0.0000 & -8.5516 & 0.0000 \\
$\ln I M P$ & $1^{\text {st }}$ difference & -10.5485 & 0.0000 & -6.1226 & 0.0000 \\
\hline \hline
\end{tabular}

Source: Authors computation from WDI (2018). All the variables are stationary at first difference.

The third step in analyzing public debt sustainability is a panel co-integration test. The test is employed to investigate whether the debt sustainability indicators, export, and import are cointegrated; cointegration implies that the $I$ (1) series are in a long-run equilibrium; they move together, although the group of them can wander arbitrarily. Cointegration between these variables is a necessary condition for debt sustainability. 
Panel cointegration tests can be carried out using tests proposed by Pedroni $(1999,2004)$ or by Kao Residual Cointegration test. Pedroni (1999) derives seven-panel cointegration test statistics. Of the seven statistics, four are based on within-dimension, and the three are based on betweendimension with a null hypothesis of no cointegration, Table 3 below presented the result of Pedroni test.

Table 3: Pedroni Residual test result

\begin{tabular}{lcccc}
\hline & Statistic & Prob. & Weighted stat. & Prob. \\
\hline Panel v-statistics & 1.108247 & 0.1339 & 0.466468 & 0.3204 \\
Panel rho-Statistic & -0.025379 & 0.4899 & 0.226572 & 0.5896 \\
Panel PP-Statistic & -3.870339 & $0.0001 * * *$ & -3.804654 & $0.0001 * * *$ \\
panel ADF- statistic & 1.544687 & 0.9388 & -0.350664 & 0.3629 \\
\hline & & Between-Dimension & \\
\hline Group rho-Statistic & 1.762812 & 0.9610 & \\
Group PP-Statistic & -5.418933 & $0.0000 * * *$ & \\
Group ADF-Statistic & 0.775672 & 0.7810 & \\
\hline \hline
\end{tabular}

Source: Authors computation using WDI data (2018) and *** represents the rejection of the null hypothesis at 1 percent significance level.

As shown in table 3, except for the Group PP-Statistic and Group ADF-Statistic test, all other tests accept the null hypothesis of no cointegration between external public debt to GDP ratio, external public debt service to export ratio, export, and import at the 5\% significance level. This test implies that in a panel perspective, external public debt is not sustainable in the long run for low-income SSA from 2000 to 2017. In addition to the panel cointegration test, time series cointegration test is applied and finds that there was no long-run relationship observed between those variables for each of low-income SSA countries. Similarly, Kao (1999) describes two tests under the null hypothesis of no cointegration for panel data. One is a Dickey-Fuller type test and another is an Augmented Dickey-Fuller type test, and from table 4, it is concluded that all the panel tests accept the null hypothesis of no cointegration between variables. 
Table 4: Kao Residual cointegration test result

\begin{tabular}{|lcc|}
\hline & Statistic & Prob. \\
\hline DF & -1.359955 & 0.0869 \\
Residual variance & 0.107172 & \\
HAC variance & 0.120998 & \\
\hline
\end{tabular}

Source: Authors computation from WDI (2018)

To sum up, the first two tests of univariate unit root and panel unit root test result shows all countries debt was unsustainable. The third necessary test of panel cointegration depicts that external public debt was unsustainable in the study area. Since exports and imports had no longrun relationship the countries faced a trade deficit. The countries must borrow from other countries and institution to pay for extra imports. Countries external debt is accumulated as a result of the foreign currency shortage. In a similar manner, there were no long-run relationships between the debt sustainability indicators. Thus, external public debt was unsustainable in lowincome SSA countries from 2000 to 2017. This unsustainable debt compels governments to spend more on debt servicing and less on education, health, and infrastructure. It also creates uncertainty, deterring investment and innovation, and has a negative impact on economic growth. In order to identify the way to treat the individual effect as a fixed or random the researcher developed two types of model namely fixed effect and random effect model. The result obtained from the fixed effect model using Stata is presented in Table 5 below.

Table 5: Estimation result of Fixed Effect model

\begin{tabular}{|c|c|c|c|}
\hline \multirow[t]{2}{*}{ Var } & \multicolumn{3}{|c|}{ Fixed Effect Model } \\
\hline & Coefficient & Std. Err. & P-value \\
\hline $\operatorname{lnEPD}$ & -.3492947 & .0279621 & $0.000 * * *$ \\
\hline $\operatorname{lnEPDS}$ & -.1743913 & .0892649 & $0.052^{*}$ \\
\hline $\operatorname{lnINV}$ & .2596801 & .0259908 & $0.000 * * *$ \\
\hline POP & -.1534773 & .0719024 & $0.034 * *$ \\
\hline $\operatorname{lnINF}$ & .0015258 & .0169436 & 0.928 \\
\hline $\operatorname{lnTOP}$ & -.4740249 & .0499799 & $0.000 * * *$ \\
\hline $\operatorname{lnDOM}$ & .2080128 & .0251467 & $0.000 * * *$ \\
\hline CONS & 16.10268 & .566514 & $0.000 * * *$ \\
\hline
\end{tabular}

Source: Authors computation from the WDI (2018). ***,**and * indicates significance level at 1,5 , and 10 percent, respectively. 
In order to decide between fixed effect and random effect model, it is mandatory to run a Hausman test where the null hypothesis is that the preferred model is random effects and the alternative is the fixed effects. Table 6 below shows the result of the Hausman test and indicates that the null hypothesis is rejected (the $\mathrm{P}$ value is less than 5). This implies that the fixed effect model is the appropriate model for estimating the relationship between external debt and economic growth in the selected countries.

Table 6: Hausman test result

\begin{tabular}{|c|c|c|c|c|}
\hline & \multicolumn{4}{|c|}{ Coefficients } \\
\hline & (b) fe & (B) re & (b-B) difference & $\begin{array}{l}\text { Sqrt (diag(V_b- } \\
\text { V_B)) S.E }\end{array}$ \\
\hline $\operatorname{lnEPD}$ & -.3492947 & -.1221099 & -.2271849 & .021433 \\
\hline $\operatorname{lnEPDS}$ & -.1743913 & -.5537162 & .3793249 & - \\
\hline $\operatorname{lnINV}$ & .2596801 & .4405002 & -.1808201 & - \\
\hline POP & -.1534773 & -.11047 & -.0430073 & - \\
\hline $\operatorname{lnINF}$ & .0015258 & -.0276158 & .0291417 & - \\
\hline $\operatorname{lnTOP}$ & -.4740249 & -.9368452 & .4628203 & .0297382 \\
\hline $\operatorname{lnDOM}$ & .2080128 & .1494465 & .0585662 & - \\
\hline \multicolumn{5}{|c|}{$\mathrm{B}=$ inconsistent under Ha, efficient under Ho; obtained from xtreg } \\
\hline \multicolumn{5}{|c|}{ Test: Ho: difference in coefficients not systematic } \\
\hline \multicolumn{2}{|c|}{ Prob $>$ chi $2=0.0000$} & & & \\
\hline
\end{tabular}

Source: Authors computation from the WDI (2018). 
Table 7: Fixed Effect model estimation test result

\begin{tabular}{lcccc}
\hline $\operatorname{lnGDP}$ & Coefficient & Robust Std.Err. & t-value & P-value \\
\hline $\operatorname{lnPED}$ & -.3492947 & .0544624 & -6.41 & $0.000^{* * *}$ \\
$\ln \mathrm{NEDS}$ & -.1743913 & .0552937 & -3.15 & $0.004^{* * *}$ \\
$\operatorname{lnINV}$ & .2596801 & .0978064 & 2.66 & $0.014^{* * *}$ \\
POP & -.1534773 & .0757545 & -2.03 & $0.055^{*}$ \\
$\operatorname{lnINF}$ & .0015258 & .0205354 & 0.07 & 0.941 \\
$\operatorname{lnTOP}$ & -.4740249 & .1282074 & -3.70 & $0.001^{* * *}$ \\
$\operatorname{lnDOM}$ & .2080128 & .0609789 & 3.41 & $0.002^{* * *}$ \\
CONS & 16.10268 & 2.009333 & 8.01 & 0.000 \\
\hline
\end{tabular}

Source: Authors computation using WDI data (2018). ***,** and * represents significant variables at $1 \%, 5 \%$ and $10 \%$ significant level, respectively.

From the above (table 7) fixed effect robust standard errors estimation result, we have seen that out of seven explanatory variables five of them are significantly affected the economic growth of low-income SSA countries from 2000 to 2017. Table 7 also shows that both external public debt to GDP ratio and external public debt service to export ratio have a negative and significant effect i.e. similar to the expected sign. Thus, on average, 1 percent increases in external public debt to GDP ratio and external public debt service to export ratio of the countries results in 34.9 and 17.4 percent reduction in economic growth, respectively. This result is consistent with the classical and monetarist theory of public debt. External debt depresses investment through both a disincentive effect and a crowding out effect and debt stock reduction would have significantly increased investment and growth performance.

Similarly, the coefficient of population growth is negative but insignificant. Unlike the expected sign, trade openness has a negative and significant effect on economic growth, trade restrictions in the form of tariffs, as well as trade-related taxes, are positively associated with economic growth. Relying on a large sample of both developing and developed countries the relationship between trade openness and growth is negative even if it depends on the level of development and the size of the economy.

However, gross investment and domestic debt have a positive and significant effect on economic growth. Domestic debt has a positive role in economic growth because the funds generated 
through domestic borrowing have been used partially to finance those expenditures of governments that contribute to the growth of GDP and long-term development purposes. According to Christensen (2004), governments may still look towards domestic borrowing because of the following reasons. Government with large recurrent budget deficit may be forced to tap into domestic savings including through the issuance of domestic debt, to close their budget gap. In addition to this domestic debt can also be used to achieve monetary policy target. This is particularly the case in countries with a large balance of payment surpluses, created by large aid inflow and this increases liquidity which could undermine macroeconomic stability and central banks often decides to intervene by selling government or central bank bills to stem inflationary pressure from excess liquidity. Finally, the inflation rate has a positive but insignificant effect in this study.

\section{CONCLUSIONS AND POLICY IMPLICATIONS}

This study examines the debt sustainability and Economic Growth of low-income SSA countries from 2000 to 2017. In order to assess the effect of external public debt on economic growth, the fixed-effect model is employed. The result of this model indicates that a significant and negative effect of external public debt to GDP and external public debt service to the export ratio on economic growth. This indicates that a higher debt burden leads to a significant portion of government revenue being devoted to debt servicing instead of being channeled to productive investment and this is a constraint to improve economic growth. As a result, GDP growth declines. A significant increase in external public debt also discourages investments by increasing uncertainty concerning government policies. An increasing external public debt stock often creates expectations that the government is likely to increase tax to meet its debt obligations. Due to this, the private sector investors are likely to postpone their investments, which in turn reduce economic growth.

The finding of this study implied that the coefficients of population growth and inflation rates are not statistically significant in the selected countries. Similarly, gross investment has a positive and significant effect on the economic growth of low-income SSA countries from 2000 to 2017. An increase in investment involves increased spending of a countries savings on capital goods that are necessary for production and is likely to increase labor productivity. The resulting increase in aggregate output leads to an improvement in GDP growth and standards of living. 
Furthermore, domestic debt in this study has a positive and significant effect on economic growth in the selected countries. Domestic debt is better for low income countries of SSA for two reasons. First, the payment is made by domestic currencies and this reduces the problem of foreign currencies shortage; second, the domestic debt interest rate is low compared with external debt. Unlike the expected positive coefficient, trade openness has a negative and significant effect. Trade liberalization reduces the productivity of the infant industry. For a newly created industry to survive, the government needs to protect it from foreign competition until its production process becomes more efficient and cost-effective.

In this study, the researcher applied econometric techniques useful to assess the sustainability of external debt. Various univariates and panel unit root test have been applied to 24 Sub Saharan low-income countries with 18 years of data. Three different techniques were applied. The first was the univariate unit root tests (ADF and PP) to know the external debt sustainability of individual countries and the result depicted nonstationary series of external public debt stock to GDP, external public debt service to exports ratios, export, and import. Thus, all the countries are facing the unsustainable level of external public debts. panel unit root tests (LL and IPS) was the second type of test and applied on low-income SSA countries as a whole to assess their external debt status. The test found that the external debt of the selected countries' economies as a whole was unsustainable.

The third type of tests includes time series and panel cointegration based approaches and found that there was no long-run relationship observed between external public debt, external public debt service, export and import for each of the selected countries (unsustainable external public debt) and panel cointegration approach declared their external debt was unsustainable as a whole. Based on the results, it can be said that the increased external debt is leading the low-income SSA countries' economies toward the low level of growth and retarding development in the economies.

Since, the objective of this study is to analyze the effect of external public debt on economic growth and to assess debt sustainability of low-income SSA. Based on the empirical results the following measures are recommended. First, there is a need to implement an appropriate policy measure in order to achieve the positive impact of external debt on economic growth through minimizing budgetary deficit, implementing import substitution policy and by adopting a balance 
between external and domestic debt so as maintain steady economic growth. Moreover, for countries with a narrow export base, there is a need for export diversification in order to widen the revenue base and reduce external borrowing for the countries to move out of debt distress.

Second, the study recommends that in order to avoid unsustainable levels of external debt all low-income SSA countries should reduce their current expenditures instead of directly going for external borrowing and reallocate their resources in the development heads. They can utilize their externally borrowed resources in production and development purposes so that the profits and better repayment capacity can make the debt sustainable. The countries may create the economic environment attracting foreign direct investment which supplements not only the countries capital stock by filling the saving-investment gap but also removes fiscal and current account deficits. The countries should export more and try hard to stable general price level, adopt measures to increase the domestic saving and investment rates, borrow from the sources having the less volatile and low-interest rate.

Finally, low-income SSA nations should examine their economic policies to see what sorts of adjustment can be made to allow them to resume debt payment. So, appropriate debt management mechanisms should be adopted and implemented to keep debt levels within sustainable limits. Specifically, the Government should invest the borrowed money on productive investments, reduces unnecessary expenditures, and try to reduce corruption. 


\section{DECLARATIONS}

$\checkmark$ Ethics approval and consent to participate 'Not applicable'

$\checkmark$ Consent for publication 'Not applicable'

$\checkmark$ Availability of data and materials

The study used panel data for 24 SSA countries that are classified as low income based on a measure of national income per person, or GNI per capita. The data covers the period between 2000 and 2017 for all variables included in the study. This paper employed data from the World Bank's World Development Indicator (WDI) database, Global Development Finance database (World Bank), and supplemented with data from the World Economic Outlook database (IMF).

The study employed seven explanatory variables so as to evaluate debt sustainability and the effect of external public debt on economic growth. The variables are external public debt, external public debt service, investment, population, inflation, trade openness, and domestic debt. In this study, both descriptive statistics and econometric methods of data analysis are employed.

\section{$\checkmark$ Competing interest}

The author declares that they have no competing interests.

\section{$\checkmark$ Funding}

The researcher does not have research funding for this paper

\section{$\checkmark$ Authors contributions}

Nitsuh Mengist Nega prepared and designed the research questions, prepare the model experiments, interpret the result, and prepare the manuscripts.

\section{$\checkmark$ Acknowledgments}

Since this study is a masters paper of Nitsuh Mengist, Graduate School of Economics, Addis Ababa University, Ethiopia, I would to thank my advisor Dr. Sisay Regassa for his valuable comments.

\section{$\checkmark$ Authors Information}

Author's Name: Nitsuh Mengist Nega 
The author completed both Bachelor of Degree (BA) in economics and Masters of Science (MSc.) in economic policy analysis from Addis Ababa University, Ethiopia. The author is now lecturer at Wolkite University, Ethiopia.

\section{APPENDICES}

\section{Appendix 1: Univariate Unit Root tests}

\begin{tabular}{ccccc}
\multicolumn{2}{l}{ Intermediate ADF test results LNPED } & & & \\
\hline Cross & & & & \\
section & Prob. & Lag & Max Lag & Obs \\
\hline Benin & 0.4251 & $\mathrm{O}$ & $\mathrm{O}$ & 17 \\
Burkinafa & 0.0264 & $\mathrm{O}$ & $\mathrm{O}$ & 17 \\
Burundi & 0.8702 & $\mathrm{O}$ & $\mathrm{O}$ & 17 \\
Centeral & 0.1625 & $\mathrm{O}$ & $\mathrm{O}$ & 17 \\
Chad & 0.1282 & $\mathrm{O}$ & $\mathrm{O}$ & 17 \\
Comoros & 0.8056 & $\mathrm{O}$ & $\mathrm{O}$ & 17 \\
Congo & 0.9176 & $\mathrm{O}$ & $\mathrm{O}$ & 17 \\
Eritrea & 0.6745 & $\mathrm{O}$ & $\mathrm{O}$ & 17 \\
Ethiopia & 0.5528 & $\mathrm{O}$ & $\mathrm{O}$ & 17 \\
Gambia & 0.9285 & $\mathrm{O}$ & $\mathrm{O}$ & 17 \\
Guinea & 0.9401 & $\mathrm{O}$ & $\mathrm{O}$ & 17 \\
Guineabissau & 0.8339 & $\mathrm{O}$ & $\mathrm{O}$ & 17 \\
Liberia & 0.7365 & $\mathrm{O}$ & $\mathrm{O}$ & 17 \\
Madagas & 0.3754 & $\mathrm{O}$ & $\mathrm{O}$ & 17 \\
Malawi & 0.3675 & $\mathrm{O}$ & $\mathrm{O}$ & 17 \\
Mali & 0.2080 & $\mathrm{O}$ & $\mathrm{O}$ & 17 \\
Mozambi & 0.5521 & $\mathrm{O}$ & $\mathrm{O}$ & 17 \\
Niger & 0.4056 & $\mathrm{O}$ & $\mathrm{O}$ & 17 \\
Rwanda & 0.5320 & $\mathrm{O}$ & $\mathrm{O}$ & 17 \\
Senegal & 0.5095 & $\mathrm{O}$ & $\mathrm{O}$ & 17 \\
Sierra Leo & 0.3545 & $\mathrm{O}$ & $\mathrm{O}$ & 17 \\
Tanzania & 0.4079 & $\mathrm{O}$ & $\mathrm{O}$ & 17 \\
Togo & 0.6731 & $\mathrm{O}$ & $\mathrm{O}$ & \\
Uganda & 0.5350 & & & \\
\hline \hline
\end{tabular}

Intermediate Phillips-Perron test results LNPED

\begin{tabular}{cccc}
\hline \hline Cross & & & \\
section & Prob. & Bandwidth & Obs \\
\hline Benin & 0.4210 & 1.0 & 17 \\
Burkinafa & 0.0220 & 2.0 & 17 \\
Burundi & 0.8702 & 0.0 & 17 \\
Centeral & 0.1751 & 2.0 & 17 \\
Chad & 0.1682 & 1.0 & 17 \\
Comoros & 0.8056 & 0.0 & 17 \\
Congo & 0.9076 & 1.0 & 17 \\
Eritrea & 0.6865 & 2.0 & 17 \\
Ethiopia & 0.4645 & 2.0 & 17 \\
Gambia & 0.9652 & 2.0 & 17 \\
Guinea & 0.9529 & 2.0 & 17 \\
Guinea bissau & 0.8652 & 3.0 & 17 \\
Liberia & 0.6935 & 2.0 & 17 \\
Madagas & 0.3754 & 0.0 & 17 \\
Malawi & 0.3675 & 0.0 & 17 \\
Mali & 0.2080 & 0.0 & 17 \\
Mozambi & 0.4386 & 2.0 & 17 \\
Niger & 0.3801 & 2.0 & 17 \\
Rwanda & 0.5169 & 1.0 & 17 \\
Senegal & 0.4496 & 2.0 & 17 \\
Sierra Leo & 0.3597 & 1.0 & 17 \\
Tanzania & 0.4001 & 1.0 & 17 \\
Togo & 0.6530 & 1.0 & 17 \\
Uganda & 0.5217 & 1.0 & 17 \\
\hline \hline
\end{tabular}


Intermediate ADF test results LNPEDS

\begin{tabular}{ccccc}
\hline \hline Cross & & & & \\
section & Prob. & Lag & Max Lag & Obs \\
\hline Benin & 0.0226 & $\mathrm{O}$ & $\mathrm{O}$ & 17 \\
Burkinafa & 0.2872 & $\mathrm{O}$ & $\mathrm{O}$ & 17 \\
Burundi & 0.6129 & $\mathrm{O}$ & $\mathrm{O}$ & 17 \\
Centeral & 0.0557 & $\mathrm{O}$ & $\mathrm{O}$ & 17 \\
Chad & 0.1600 & $\mathrm{O}$ & $\mathrm{O}$ & 17 \\
Comoros & 0.3301 & $\mathrm{O}$ & $\mathrm{O}$ & 17 \\
Congo & 0.3317 & $\mathrm{O}$ & $\mathrm{O}$ & 17 \\
Eritrea & 0.1225 & $\mathrm{O}$ & $\mathrm{O}$ & 17 \\
Ethiopia & 0.8989 & $\mathrm{O}$ & $\mathrm{O}$ & 17 \\
Gambia & 0.4140 & $\mathrm{O}$ & $\mathrm{O}$ & 17 \\
Guinea & 0.9237 & $\mathrm{O}$ & $\mathrm{O}$ & 17 \\
Guinea bissau & 0.1080 & $\mathrm{O}$ & $\mathrm{O}$ & 17 \\
Liberia & 0.0044 & $\mathrm{O}$ & $\mathrm{O}$ & 17 \\
Madagas & 0.1976 & $\mathrm{O}$ & $\mathrm{O}$ & 17 \\
Malawi & 0.3540 & $\mathrm{O}$ & $\mathrm{O}$ & 17 \\
Mali & 0.1030 & $\mathrm{O}$ & $\mathrm{O}$ & 17 \\
Mozambi & 0.3132 & $\mathrm{O}$ & $\mathrm{O}$ & 17 \\
Niger & 0.6548 & $\mathrm{O}$ & $\mathrm{O}$ & 17 \\
Rwanda & 0.2807 & $\mathrm{O}$ & $\mathrm{O}$ & 17 \\
Senegal & 0.2169 & $\mathrm{O}$ & $\mathrm{O}$ & 17 \\
Sierra Leo & 0.3860 & $\mathrm{O}$ & $\mathrm{O}$ & 17 \\
Tanzania & 0.3482 & $\mathrm{O}$ & $\mathrm{O}$ & 17 \\
Togo & 0.0777 & $\mathrm{O}$ & $\mathrm{O}$ & 17 \\
Uganda & 0.5741 & &
\end{tabular}

Intermediate Phillips-Perron test results LNPEDS

\begin{tabular}{cccc}
\hline \hline Cross & & & \\
section & Prob. & Bandwidth & Obs \\
\hline Benin & 0.8697 & 2.0 & 17 \\
Burkinafa & 0.9341 & 2.0 & 17 \\
Burundi & 0.4533 & 1.0 & 17 \\
Centeral & 0.3762 & 1.0 & 17 \\
Chad & 0.6282 & 1.0 & 17 \\
Comoros & 0.8663 & 14.0 & 17 \\
Congo & 0.7406 & 16.0 & 17 \\
Eritrea & 0.1271 & 1.0 & 17 \\
Ethiopia & 0.2105 & 1.0 & 17 \\
Gambia & 0.1265 & 16.0 & 17 \\
Guinea & 0.9986 & 4.0 & 17 \\
Guineabissau & 0.7445 & 2.0 & 17 \\
Liberia & 0.0370 & 6.0 & 17 \\
Madagas & 0.7823 & 6.0 & 17 \\
Malawi & 0.8289 & 2.0 & 17 \\
Mali & 0.8522 & 1.0 & 17 \\
Mozambi & 0.6810 & 0.0 & 17 \\
Niger & 0.4399 & 1.0 & 17 \\
Rwanda & 0.8018 & 2.0 & 17 \\
Senegal & 0.6935 & 2.0 & 17 \\
Sierra Leo & 0.7649 & 1.0 & 17 \\
Tanzania & 0.6339 & 1.0 & 17 \\
Togo & 0.5158 & 1.0 & 17 \\
Uganda & 0.7220 & 0.0 & 17 \\
\hline \hline
\end{tabular}

\section{REFERENCE}

Akgay, O. C., Alper, C. E., \& Ozmucur, S. (2018). Budget Deficit, Inflation and Debt Sustainability: Evidence from Turkey, 1970-2000. In Inflation and disinflation in Turkey (pp. 83-102). Routledge.

Bal, D. P., \& Rath, B. N. (2014). Public debt and economic growth in India: A reassessment. Economic Analysis and Policy, 44(3), 292-300.

Chudik, A., Mohaddes, K., Pesaran, M. H., \& Raissi, M. (2017). Is there a debt-threshold effect on output growth?. Review of Economics and Statistics, 99(1), 135-150. 
Eberhardt, M., \& Presbitero, A. F. (2015). Public debt and growth: Heterogeneity and nonlinearity. Journal of International Economics, 97(1), 45-58.

Greene, J. E., \& Khan, M. S. (1990). African debt crisis. Initiatives, Nairobi, KE.

Harl, N. E. (1990). The farm debt crisis of the 1980s. Iowa State University Press.

Irwin, T. C. (2015). Defining the government's debt and deficit. Journal of Economic Surveys, 29(4), 711-732.

Iyoha, M. A. (1999). External debt and economic growth in sub-Saharan African countries: An econometric study.

Kim, E., Ha, Y., \& Kim, S. (2017). Public debt, corruption, and sustainable economic growth. Sustainability, 9(3), 433.

Kourtellos, A., Stengos, T., \& Tan, C. M. (2013). The effect of public debt on growth in multiple regimes. Journal of Macroeconomics, 38, 35-43.

Moss, T. J., \& Chiang, H. S. (2003). The other costs of high debt in poor countries: Growth, policy dynamics, and institutions.

Ndikumana, L., Boyce, J. K., \& Ndiaye, A. S. (2013). Capital flight: measurement and drivers. In I. Ajayi \& L. Ndikumana (Eds.), Capital Flight from Africa: Causes, Effects, and Policy Issues.

Panizza, U., \& Presbitero, A. F. (2014). Public debt and economic growth: is there a causal effect?. Journal of Macroeconomics, 41, 21-41.

Presbitero, A. F. (2006). The debt-growth nexus: A dynamic panel data estimation. Rivista Italiana degli economist, 11(3), 417-462.

Reinhart, C. M., Reinhart, V. R., \& Rogoff, K. S. (2012). Public debt overhangs: advancedeconomy episodes since 1800. Journal of Economic Perspectives, 26(3), 69-86. 
Siddique, A., Selvanathan, E. A., \& Selvanathan, S. (2016). The impact of external debt on growth: Evidence from highly indebted poor countries. Journal of Policy Modeling, 38(5), 874-894.

United Nations Conference on Trade and Development, \& UNCTAD-Civil Society Dialogue. (2002). UNCTAD-Civil Society Dialogue: on Selected Development Issues Being Addressed by the United Nations System (Geneva, 10 December 2001): Papers Prepared in Support of the Issues Discussed. New York: United Nations.

Vlastou, I. (2010). Forcing Africa to open up to trade: is it worth it?. The Journal of Developing Areas, 25-39. 
Figures

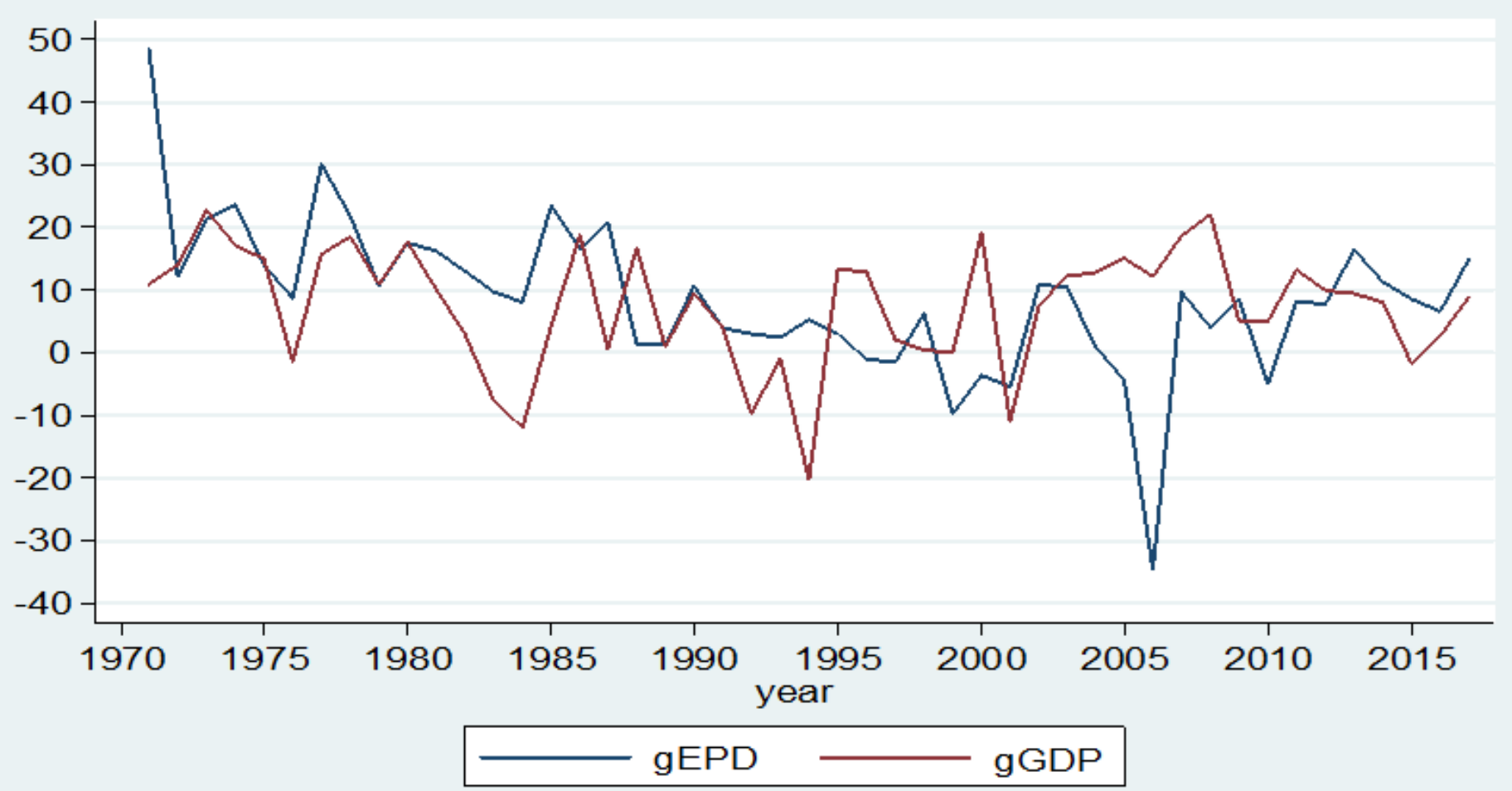

rate of external public debt and GDP of all low income countries excluding Somalia and South Sudan. source:World Development Indicator (2018)

Figure 1

external public debt and economic growth of low-income SSA from 1970 to 2017. 


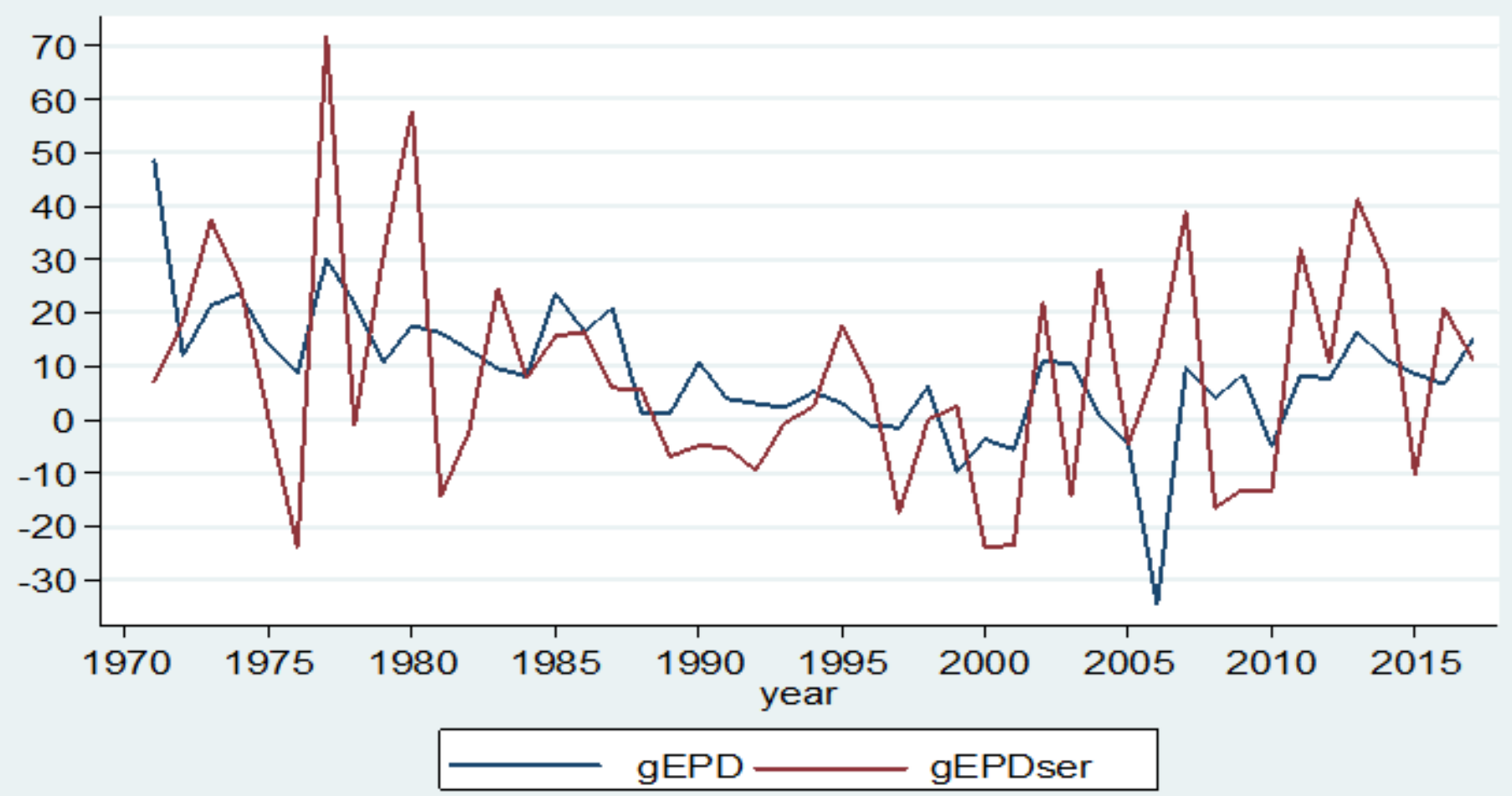

All low income Sub Sahara African countries except Somalia and South Sudan

Source: World Development Indicator (2018)

Figure 2

external public debt and external public debt service of low-income SSA from 1970 to 2017.

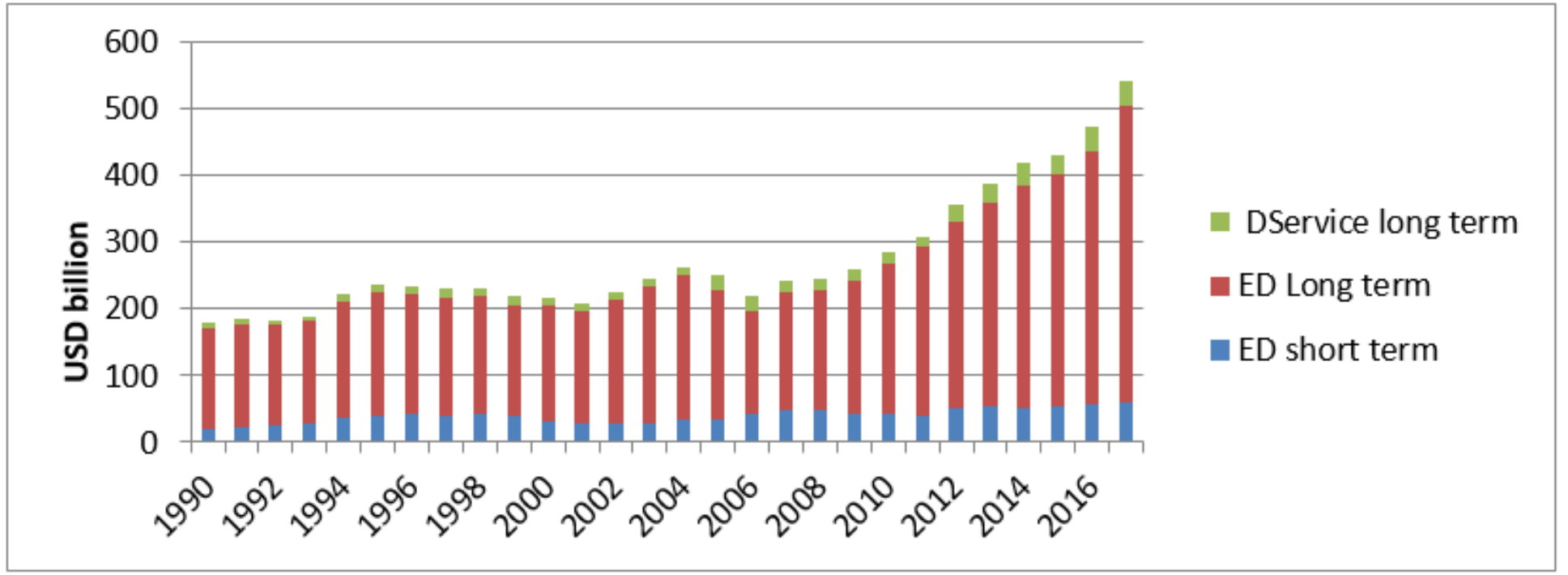

\section{Figure 3}

Composition of SSA total external debt and debt payment between years 1990 and 2017. Data for Seychelles, Somalia, and South Sudan not available 


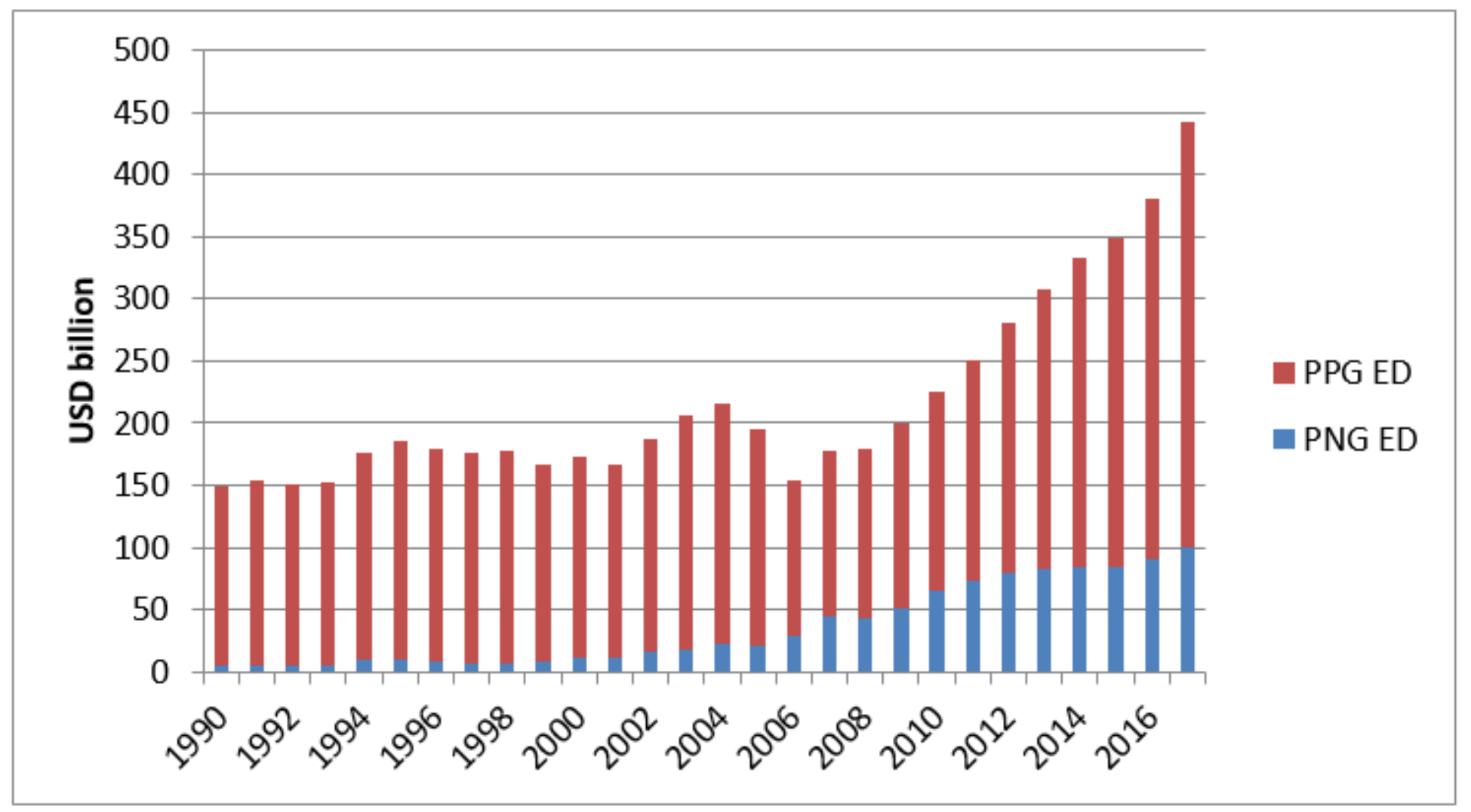

Figure 4

Composition of SSA long term external debt from 1990 to 2017. Data for Seychelles, Somalia, and South Sudan not available

\section{Supplementary Files}

This is a list of supplementary files associated with this preprint. Click to download.

- APPENDICES.docx 